\title{
Changes in ocean properties associated with Hurricane Isabel
}

\author{
R. GAUTAM $\dagger$, R. P. SINGH ${ }^{* \dagger \dagger}+$ and M. KAFATOS $\dagger$ \\ $\dagger$ School of Computational Sciences, George Mason University, Fairfax, \\ VA 22030, USA \\ †Department of Civil Engineering, Indian Institute of Technology, Kanpur \\ 208016, India
}

(Received 22 January 2004; in final form 13 July 2004)

\begin{abstract}
This Letter analyses changes in ocean colour properties caused by hurricane Isabel. Isabel hit the east coast of the USA on 18 September 2003 causing excessive rainfall and unprecedented flooding. This resulted in drastic changes in land and coastal ocean water bodies. The present study involves the use of Moderate Resolution Imaging Spectroradiometer (MODIS) data for mapping the changes in ocean colour brought by Isabel. Significant increases in the chlorophyll and suspended matter concentrations were found along the entire eastern coastline. Higher rainfall estimated by the Tropical Rainfall Measuring Mission (TRMM) Microwave Imager (TMI) and wind speed estimated by the Quick Scatterometer (QuikSCAT) were found, associated with hurricane Isabel, and are responsible for the changes in ocean colour properties.
\end{abstract}

\section{Introduction}

Hurricanes are natural hazards that originate over the oceans and, thereby disturb the equilibrium between land, ocean and atmosphere. Hurricanes are often termed cyclones or typhoons depending on their geographic location. Remote sensing has been found to be very useful in mapping natural hazards (Kundu et al. 2001, Singh et al. 2002). Natural hazards cause a lot of damage to the infrastructure of human societies leading to large losses in economy and in many cases human death. Therefore, natural hazards need to be monitored and analysed continuously for better understanding and management.

Hurricane Isabel (Category 5) struck the eastern coast of the USA in September 2003, affecting the lives of people living on the coastal areas. Isabel was the most intense hurricane in 2003. It resulted in significant changes in land, ocean and atmospheric properties from the day it was formed (7 September) to the day it made landfall (18 September). The maximum wind speed was 183 knots $\left(94 \mathrm{~m} \mathrm{~s}^{-1}\right)$ over the eye-wall and a minimum pressure of $920 \mathrm{mb}$ was observed (http://www. hurricanehunters.com/isabel.htm). Strong gusts of wind and unprecedented rainfall resulted over the east coast region as the hurricane approached the coast. Because of the rainfall, the coastal regions were flooded resulting in significant land cover

\footnotetext{
*Corresponding author; e-mail: rsingh3@gmu.edu
} 


\section{R. Gautam et al.}

changes and also in ocean water along the east coast of the USA. This affected the lives of thousands of people due to power failures, excess flooding and damage to dwellings, crops and forest cover for more than a week. Due to intense flooding and rainfall, surface runoff to the coastal ocean water increased which in turn led to changes in water quality along the coast.

Changes in land and oceanic properties due to cyclones have been discussed by Kundu et al. (2001). Physical, chemical and biological constituents and processes have been found to be interlinked with each other (Tang et al. 2002). Properties associated with oceans, such as chlorophyll and suspended matter concentrations, sea surface temperature, ocean fronts and eddies, and dissolved organic matter play a vital role in the ocean dynamics and their interaction with the atmosphere. Distribution of chlorophyll concentration variability due to wind stress has been discussed in the past (Thomas et al. 2001, 2003, Asanuma et al. 2003). Peierls et al. (2003) have recently studied the impact of three sequential hurricanes in autumn 1999 and have found a significant decrease in ocean properties. Similar changes in water constituents have also been observed in the Potomac River and Chesapeake Bay regions post-Isabel (Maryland Department of Natural Resources 2003). These observations have been carried out using ground-based stations located near Chesapeake Bay and the Potomac River, pre- and post-Isabel. Also, algal blooms have been reported during Isabel in the Potomac River and Chesapeake Bay regions.

In this Letter, we discuss the changes in chlorophyll and suspended matter concentrations in the mid-Atlantic Ocean prior to and after hurricane Isabel made landfall using Moderate Resolution Imaging Spectroradiometer (MODIS) data. We have also analysed accumulated rainfall and wind speed near the east coast region estimated by Tropical Rainfall Measuring Mission (TRMM) Microwave Imager (TMI) and Quick Scatterometer (QuikSCAT), respectively, to determine their effect on producing changes in chlorophyll and suspended matter concentrations at the ocean surface.

\section{Datasets and methodology}

MODIS coverage is onboard two satellites, Terra and Aqua, with a return frequency of twice a day; the ocean colour products are collected only during the daytime. MODIS operates in 36 frequency channels in the visible to infrared wavelength range. The spatial resolution varies between $250 \mathrm{~m}, 500 \mathrm{~m}$ and $1 \mathrm{~km}$; the ocean colour data used in the present study were of $1 \mathrm{~km}$ spatial resolution.

MODIS ocean product data were used for changes in mapping ocean properties associated with Isabel. This product was obtained from http://daac.gsfc.nasa.gov/ data. The ocean products (chlorophyll and suspended matter concentrations) are routinely produced using MODIS bio-optical algorithms in which the sea surface spectral radiance ratios are related empirically as given below (Clark 2001):

$$
\log \text { product }=A(\log X)^{3}+B(\log X)^{2}+C(\log X)+D / E
$$

where $A, B, C$ and $D$ are least squares regression coefficients, and $E$ is a constant for offsetting the derived relationship (presently set to 1),

$X=[(e) n L w($ band 9$)+(f) n L w($ band 10 $)+(g) n L w($ band 11) $] / n L w($ band 12$)$

where the wavelength bands 9, 10, 11, and 12 are centred at 442, 487, 530, and $547 \mathrm{~nm}$, respectively. Also, $e, f$, and $g$ are set to zero or one to select band 
combinations, $n L w$ is the MODIS total band solar normalized water-leaving radiance.

Wind speed data were provided by NASA's QuikSCAT (http://www.ssmi.com). The data were mapped onto a $0.25^{\circ}$ by $0.25^{\circ}$ Earth grid. QuikSCAT measures nearsurface wind speeds by calculating the backscattering of the radar pulses. Finally, daily rainfall data were provided by TRMM (http://lake.nascom.nasa.gov/tovas/); the spatial resolution of these data is $1^{\circ} \times 1^{\circ}$ with a return frequency of once per day.

\section{Results and discussion}

Figure 1 shows the track of hurricane Isabel from 7-18 September 2003. Figures 2 and 3 show the chlorophyll and suspended matter concentrations of the east coast on different days including prior to (2 September 2003) and after (19 and 30 September 2003) the hurricane made landfall. The chlorophyll concentration near the entire east coast line shows a considerable increase after Isabel made landfall compared to before the hurricane. The upwelling in the bay areas along the coast can be attributed to heavy rainfall and excess wind speed (figure 4). Large amounts of rainfall cause flooding of rivers and their tributaries, also observed after Isabel. High rainfall in the previous year, 2002, resulted in saturated ground conditions; as a result, extensive surface runoff through rivers and their tributaries fed the Chesapeake Bay and coastal bays (Maryland Department of Natural Resources 2003). Consequently, large amounts of organic nutrients through surface runoff moved into the coastal ocean regions, leading to an increase in nutrients in the bay and coastal regions. Generally, the availability of nutrients is high during warm weather conditions. The increase in chlorophyll concentration along the entire east coastline with the progress of Isabel towards the coast, until one day after (19 September 2003) Isabel made landfall, can be seen from table 1 and figure 2.

Apart from the surface runoff, strong winds are always associated with

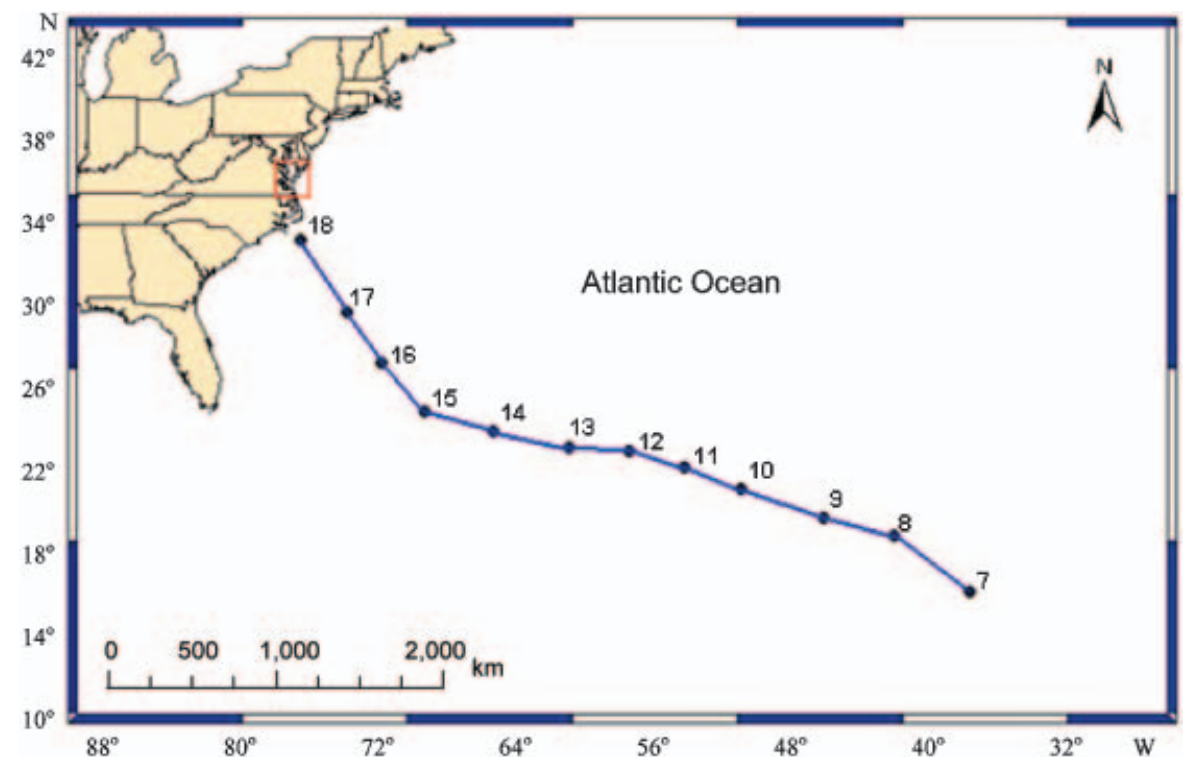

Figure 1. Track of hurricane Isabel for 7-18 September 2003. The study area covering Chesapeake Bay (red box) is selected for quantitative evaluation of changes in chlorophyll concentration, accumulated rainfall and wind speed. 


\section{R. Gautam et al.}

$\left(82^{\circ} 34^{\prime} \mathrm{W}, 38^{\circ} 30^{\prime} \mathrm{N}\right)$

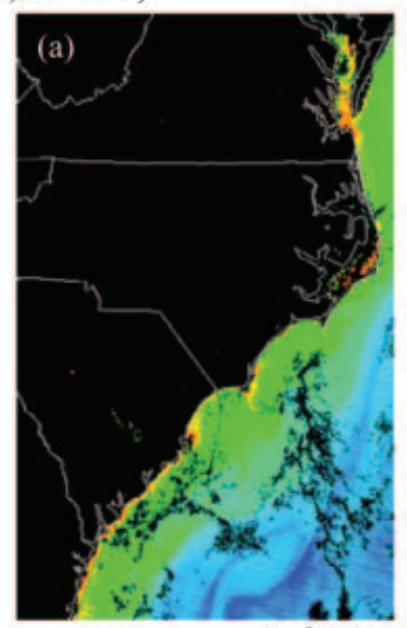

$\left(75^{\circ} 22^{\prime} \mathrm{W}, 31^{\circ} 14^{\prime} \mathrm{N}\right)$ $\left(82^{\circ} 34^{\prime} \mathrm{W}, 38^{\circ} 30^{\prime} \mathrm{N}\right)$

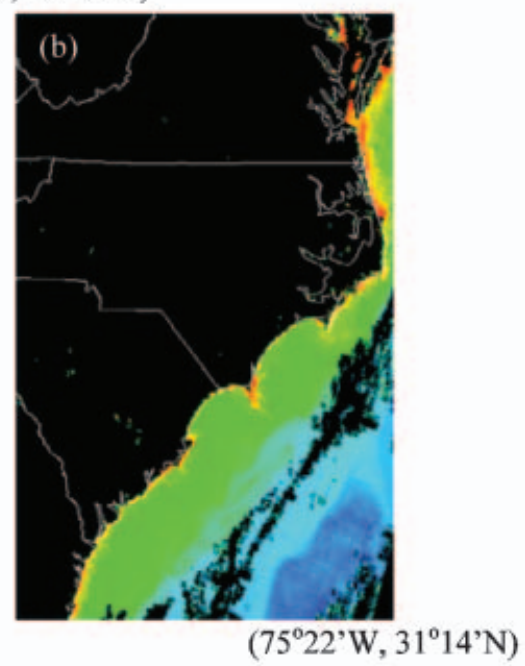

$\left(82^{\circ} 34^{\prime} \mathrm{W}, 38^{\circ} 30^{\prime} \mathrm{N}\right)$
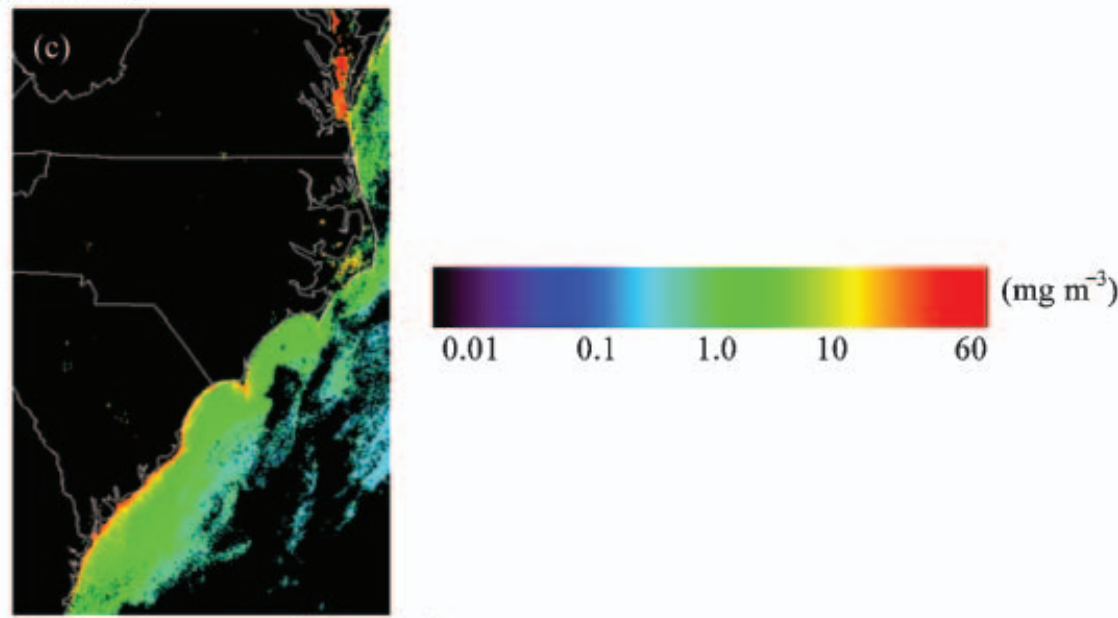

$\left(75^{\circ} 22^{\prime} \mathrm{W}, 31^{\circ} 14^{\prime} \mathrm{N}\right)$

Figure 2. Chlorophyll concentration along the east coast on (a) 2, (b) 19 and (c) 30 September 2003.

hurricanes, which are also responsible for the increase in chlorophyll concentration (Cahoon et al. 2001, Huyer 2003). Strong winds intensify the roughness of the ocean surface and cause mixing among different oceanic layers leading to the increase in chlorophyll concentration on 30 September 2003 (table 1).

Similar to the chlorophyll concentration, changes in the suspended matter concentration were also found associated with hurricane Isabel (figure 3). A decrease in water clarity (increased turbidity) throughout the Chesapeake and coastal bay regions was found from the ground station data (Maryland Department of Natural Resources 2003). An increase in suspended matter concentration can therefore be attributed to the increased sediment loading, as a result of shoreline erosion at river mouths. Strong wind gusts cause ocean water mixing, which in turn results in upwelling of the sediments at the bottom of the ocean. The increase in 
$\left(82^{\circ} 34^{\prime} \mathrm{W}, 38^{\circ} 30^{\prime} \mathrm{N}\right)$

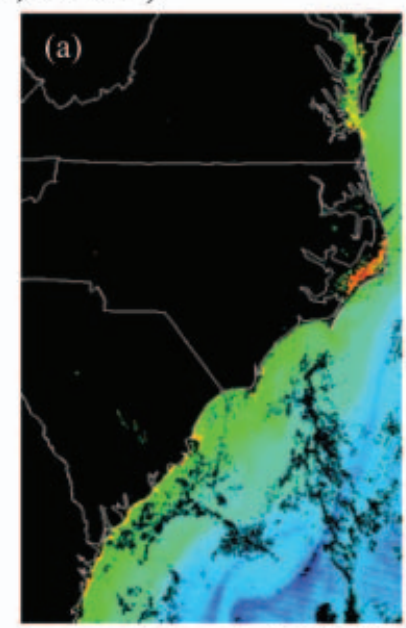

$\left(75^{\circ} 22^{\prime} \mathrm{W}, 31^{\circ} 14^{\prime} \mathrm{N}\right)$ $\left(82^{\circ} 34^{\prime} \mathrm{W}, 38^{\circ} 30^{\prime} \mathrm{N}\right)$

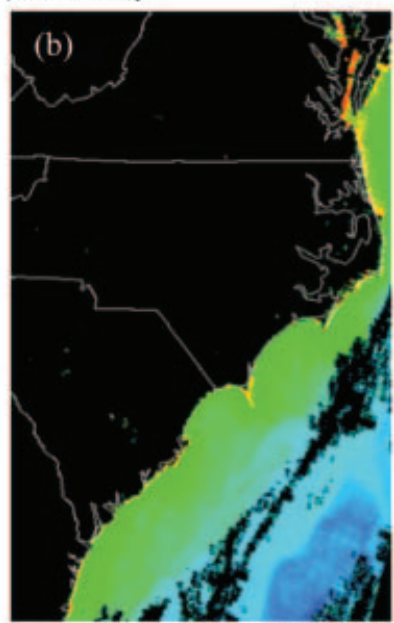

$\left(75^{\circ} 22^{\prime} \mathrm{W}, 31^{\circ} 14^{\prime} \mathrm{N}\right)$

$\left(82^{\circ} 34^{\prime} \mathrm{W}, 38^{\circ} 30^{\prime} \mathrm{N}\right)$
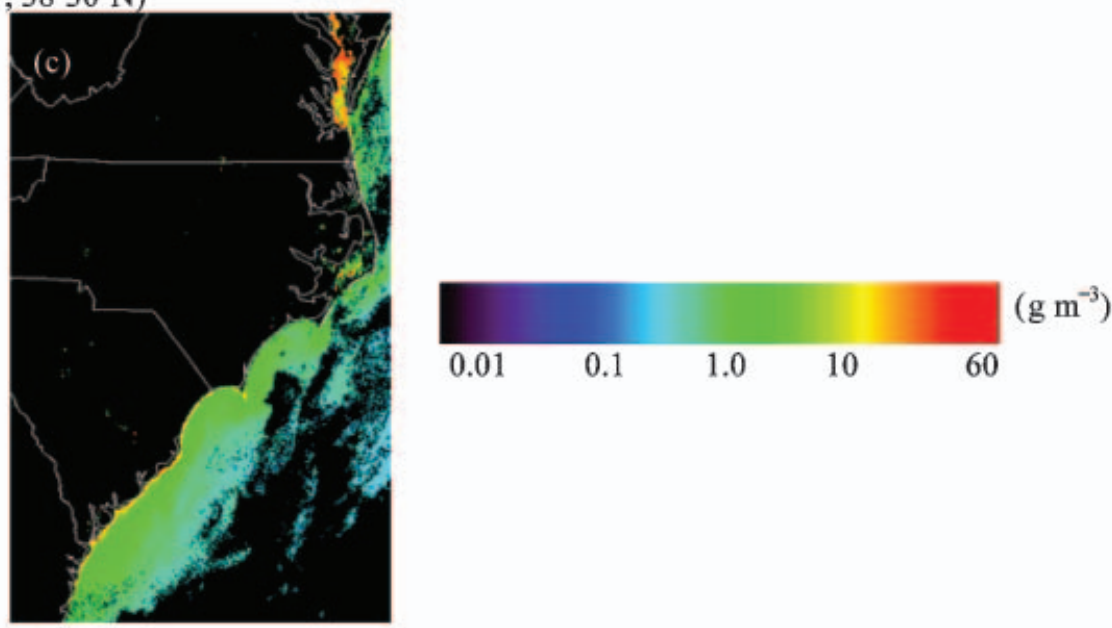

$\left(75^{\circ} 22^{\prime} \mathrm{W}, 31^{\circ} 14^{\prime} \mathrm{N}\right)$

Figure 3. Suspended matter concentration along the east coast on (a) 2, (b) 19 and (c) 30 September 2003.

suspended matter concentration is found mainly close to the coast due to shoreline erosion (figure 3); while the chlorophyll concentration is found to increase near as well as far from the coast. High wind speeds also cause shoreline erosion, thus increasing the suspended matter concentration. The abundance of suspended sediments may become harmful for the fish population (Castro and Reckendorf 1995), but at the same time optimum suspended matter concentration generally helps in the growth of marine life.

Due to cloud cover, it was difficult to obtain a clear image for other dates and also it was difficult to obtain the same scene to allow further quantitative estimation of changes. However, with limited data we have extracted the chlorophyll concentration, rainfall and wind speed of the area bounded by $37.2^{\circ} \mathrm{N}, 76.3^{\circ} \mathrm{W}$ and $36.5^{\circ} \mathrm{N}, 75.3^{\circ} \mathrm{W}$; table 1 shows the average and maximum chlorophyll concentration 

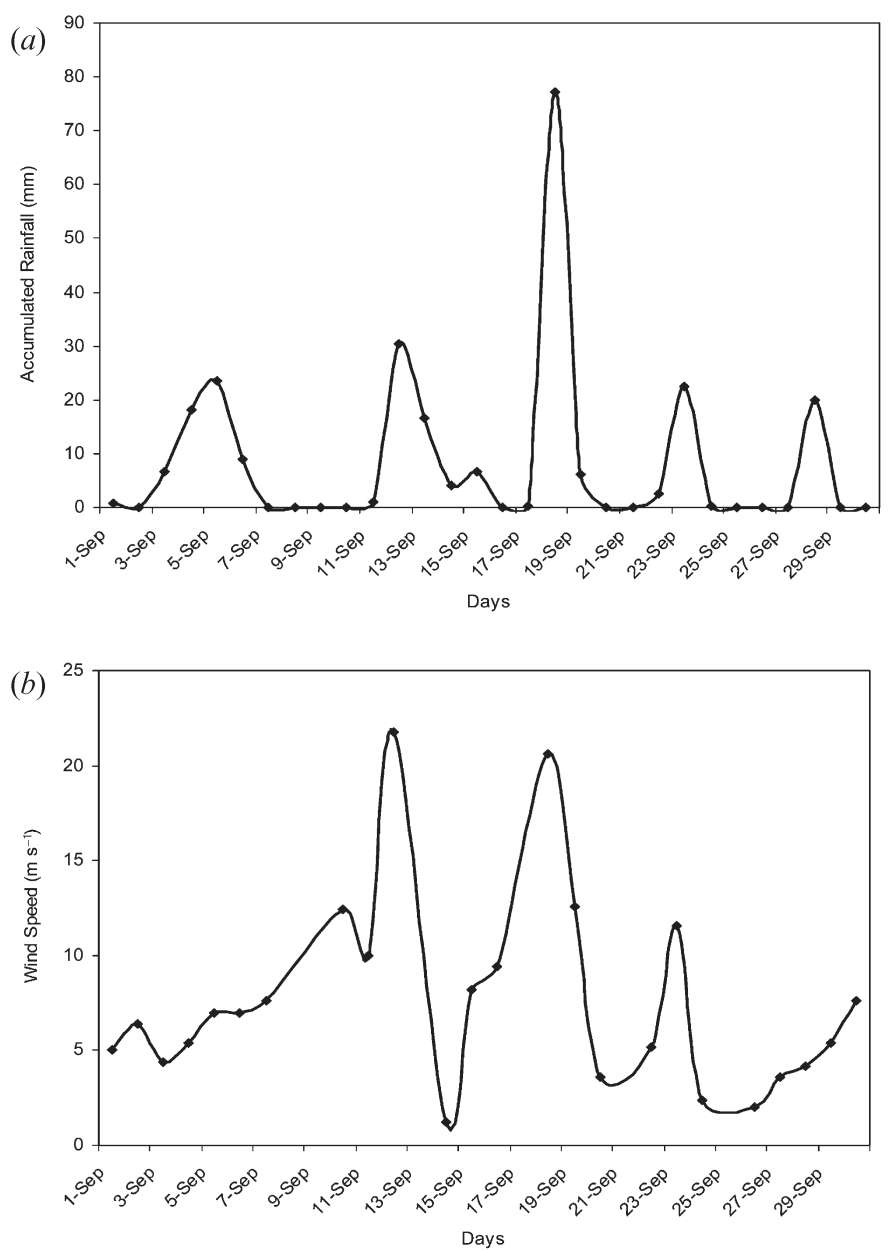

Figure 4. Variation of $(a)$ accumulated rainfall and $(b)$ wind speed in the area bounded by $37.2^{\circ} \mathrm{N}, 76.3^{\circ} \mathrm{W}$ and $36.5^{\circ} \mathrm{N}, 75.3^{\circ} \mathrm{W}$ during September 2003.

prior to and after Isabel. The accumulated rainfall (figure 4(a)) and wind speed (figure 4(b)) show significant changes with the progress of Isabel towards the east coast.

\section{Conclusions}

The present results show qualitative changes in chlorophyll and suspended matter concentrations associated with hurricane Isabel, which hit the eastern coast of the USA on 18 September 2003. Because of this hurricane, the mid-Atlantic

Table 1. Quantitative variation of chlorophyll concentration $\left(\mathrm{mg} \mathrm{m}^{-3}\right)$ in the area bounded by $\left(37.2^{\circ} \mathrm{N}, 76.3^{\circ} \mathrm{W}\right)$ and $\left(36.5^{\circ} \mathrm{N}, 75.3^{\circ} \mathrm{W}\right)$.

\begin{tabular}{lcccccc}
\hline & $\begin{array}{c}27 \\
\text { August } \\
2003\end{array}$ & $\begin{array}{c}29 \\
\text { August }\end{array}$ & $\begin{array}{c}2 \\
\text { September } \\
2003\end{array}$ & $\begin{array}{c}19 \\
\text { September }\end{array}$ & $\begin{array}{c}21 \\
\text { September } \\
2003\end{array}$ & $\begin{array}{c}30 \\
\text { September } \\
2003\end{array}$ \\
\hline Average $\left(\mathrm{mg} \mathrm{m}^{-3}\right)$ & 4.33 & 4.64 & 9.75 & 12.33 & 5.31 & 12.31 \\
Maximum $\left(\mathrm{mg} \mathrm{m}^{-3}\right)$ & 50.30 & 61.16 & 87.17 & 94.95 & 65.18 & 93.29 \\
\hline
\end{tabular}


region was covered with intense clouds, and consequently, chlorophyll and suspended matter concentration data were limited to a few days only. The satellite remote sensing data clearly show changes in rainfall and wind speed with the progress of Isabel that are responsible for changes in weather conditions and also the changes associated with chlorophyll and suspended matter concentrations.

\section{Acknowledgments}

The MODIS and TRMM data were obtained from the NASA Distributed Active Archive Center (DAAC) and QuikSCAT data from www.ssmi.com. The work is supported by the VAccess MAGIC projects, Center for Earth Observing and Space Research (CEOSR), George Mason University. We are grateful to the two anonymous reviewers and to Professor Peter Atkinson, Letter Editor, for their useful comments, which helped us to improve the earlier version.

\section{References}

Asanuma, I., Matsumoto, K., Okano, H., Kawano, T., Hendiarti, N., and Sachoemar, S. I., 2003, Spatial distribution of phytoplankton along the Sunda Islands: the monsoon anomaly in 1998. Journal of Geophysical Research, 108, 3202.

Cahoon, L. B., Mallin, M. A., Bingham, F. M., Kissling, S. A., and Nearhoof, J. E., 2001, Monitoring the coastal ocean: responses to Hurricane Floyd. In Facing Our Future: Hurricane Floyd and Recovery in the Coastal Plain, edited by J. R. Maiolo, J. C. Whitehead, M. McGee, L. King, J. Johnson and H. Stone (Wilmington, NC: Coastal Carolina Press), pp. 247-253.

CAstro, J., and Reckendorf, F., 1995, Effects of sediment on the aquatic environment. Potential NRCS Action to Improve Aquatic Habitat Working Paper No.6. http:// www.hhq.nrcs.usda.gov/RCA.PAPERS/WP06/wp06text.html.

ClARK, D. K., 2001, MOD19 Data Quality Summary. http://modis-ocean.gsfc.nasa.gov/qa/ terra/dataqualsum/chlorMODIS_qualsum.pdf.

HuYer, A., 2003, Preface to special section on enhanced subarctic influence in the California Current, 2002. Geophysical Research Letters, 30, 8019.

Kundu, S. N., Sahoo, A. K., Mohapatra, S., and Singh, R. P., 2001, Change analysis using IRS-P4 OCM data after the Orissa super cyclone. International Journal of Remote Sensing, 22, 1383-1389.

Maryland Department of NATURAl Resources, 2003, Impacts of Hurricane Isabel on Maryland's Aquatic Resources: Initial assessment. http://www.dnr.state.md.us/bay/ isabel_impacts.pdf.

Peierls, P. B., Christian, R. R., and Paerl, H. W., 2003, Water quality and phytoplankton as indicators of hurricane impacts on a large estuarine ecosystem. Estuaries, 26, 1329-1343.

Singh, R. P., BhOI, S., and SAHoo, A. K., 2002, Changes observed in land and ocean after Gujarat earthquake of 26 January 2001 using IRS data. International Journal of Remote Sensing, 23, 3123-3128.

TAnG, D. L., Kawamura, H., and Luis, A. J., 2002, Short-term variability of Phytoplankton blooms associated with a cold eddy in the northeastern Arabian Sea. Remote Sensing of Environment, 81, 82-89.

Thomas, A. C., Carr, M. E., and Strub, P. T., 2001, Chlorophyll variability in eastern boundary currents. Geophysical Research Letters, 28, 3421-3424.

Thomas, A. C., Strub, P. T., Carr, M. E., and Weatherbee, R., 2003, Comparisons of chlorophyll variability between the four major global eastern boundary currents. International Journal of Remote Sensing, 24, 1-5. 